\title{
Fabrication and Testing of a Thin-Film Heat Flux Sensor for a Stirling Convertor
}

Scott D. Wilson

Sest, Inc., Middleburg Heights, Ohio

Gus C. Fralick, John D. Wrbanek, and Ali Sayir

Glenn Research Center, Cleveland, Ohio 


\section{NASA STI Program . . . in Profile}

Since its founding, NASA has been dedicated to the advancement of aeronautics and space science. The NASA Scientific and Technical Information (STI) program plays a key part in helping NASA maintain this important role.

The NASA STI Program operates under the auspices of the Agency Chief Information Officer. It collects, organizes, provides for archiving, and disseminates NASA's STI. The NASA STI program provides access to the NASA Aeronautics and Space Database and its public interface, the NASA Technical Reports Server, thus providing one of the largest collections of aeronautical and space science STI in the world. Results are published in both non-NASA channels and by NASA in the NASA STI Report Series, which includes the following report types:

- TECHNICAL PUBLICATION. Reports of completed research or a major significant phase of research that present the results of NASA programs and include extensive data or theoretical analysis. Includes compilations of significant scientific and technical data and information deemed to be of continuing reference value. NASA counterpart of peer-reviewed formal professional papers but has less stringent limitations on manuscript length and extent of graphic presentations.

- TECHNICAL MEMORANDUM. Scientific and technical findings that are preliminary or of specialized interest, e.g., quick release reports, working papers, and bibliographies that contain minimal annotation. Does not contain extensive analysis.

- CONTRACTOR REPORT. Scientific and technical findings by NASA-sponsored contractors and grantees.
- CONFERENCE PUBLICATION. Collected papers from scientific and technical conferences, symposia, seminars, or other meetings sponsored or cosponsored by NASA.

- SPECIAL PUBLICATION. Scientific, technical, or historical information from NASA programs, projects, and missions, often concerned with subjects having substantial public interest.

- TECHNICAL TRANSLATION. Englishlanguage translations of foreign scientific and technical material pertinent to NASA's mission.

Specialized services also include creating custom thesauri, building customized databases, organizing and publishing research results.

For more information about the NASA STI program, see the following:

- Access the NASA STI program home page at http://www.sti.nasa.gov

- E-mail your question via the Internet to help@ sti.nasa.gov

- Fax your question to the NASA STI Help Desk at $443-757-5803$

- Telephone the NASA STI Help Desk at 443-757-5802

- Write to: NASA Center for AeroSpace Information (CASI) 7115 Standard Drive Hanover, MD 21076-1320 
NASA/TM-2010-216063

AIAA-2009-4581

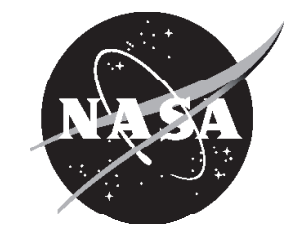

\section{Fabrication and Testing of a Thin-Film Heat Flux Sensor for a Stirling Convertor}

Scott D. Wilson

Sest, Inc., Middleburg Heights, Ohio

Gus C. Fralick, John D. Wrbanek, and Ali Sayir

Glenn Research Center, Cleveland, Ohio

Prepared for the

Seventh International Energy Conversion Engineering Conference (IECEC)

sponsored by the American Institute of Aeronautics and Astronautics

Denver, Colorado, August 2-5, 2009

Prepared under NNCO8JF19T

National Aeronautics and

Space Administration

Glenn Research Center

Cleveland, Ohio 44135 


\section{Acknowledgments}

This work is funded through the National Aeronautics and Space Administration (NASA) Science Mission Directorate and was supported by the NASA Glenn Research Center Contract NNCO8JF19T. The authors wish to acknowledge invaluable contributions from Art Atherton, Charles Blaha, Terrell Jansen, Nissim Lugasy, and Tom Sabo.

This report is a formal draft or working paper, intended to solicit comments and ideas from a technical peer group.

This report contains preliminary findings, subject to revision as analysis proceeds.

Trade names and trademarks are used in this report for identification only. Their usage does not constitute an official endorsement, either expressed or implied, by the National Aeronautics and Space Administration.

Level of Review: This material has been technically reviewed by technical management.

Available from

NASA Center for Aerospace Information 7115 Standard Drive

Hanover, MD 21076-1320
National Technical Information Service 5285 Port Royal Road Springfield, VA 22161 


\title{
Fabrication and Testing of a Thin-Film Heat Flux Sensor for a Stirling Convertor
}

\author{
Scott D. Wilson \\ Sest, Inc. \\ Middleburg Heights, Ohio 44130 \\ Gus C. Fralick, John D. Wrbanek, and Ali Sayir \\ National Aeronautics and Space Administration \\ Glenn Research Center \\ Cleveland, Ohio 44135
}

\begin{abstract}
The NASA Glenn Research Center (GRC) has been testing high-efficiency free-piston Stirling convertors for potential use in radioisotope power systems since 1999. Stirling convertors are being operated for many years to demonstrate a radioisotope power system capable of providing reliable power for potential multiyear missions. Techniques used to monitor the convertors for change in performance include measurements of temperature, pressure, energy addition, and energy rejection. Micro-porous bulk insulation is used in the Stirling convertor test setup to minimize the loss of thermal energy from the electric heat source to the environment. The insulation is characterized before extended operation, enabling correlation of the net thermal energy addition to the convertor. Aging micro-porous bulk insulation changes insulation efficiency, introducing errors in the correlation for net thermal energy addition. A thin-film heat flux sensor was designed and fabricated to directly measure the net thermal energy addition to the Stirling convertor. The fabrication techniques include slipcasting and using Physical Vapor Deposition (PVD). One-micron-thick noble metal thermocouples measure temperature on the surface of an alumina ceramic disk and heat flux is calculated. Fabrication, integration, and test results of a thin-film heat flux sensor are presented.
\end{abstract}

\section{Nomenclature}

$\begin{array}{ll}\text { ASC } & \text { Advanced Stirling Convertor } \\ \text { ASC-E } & \text { Advanced Stirling Convertor Engineering Unit } \\ \text { ASC-E2 } & \text { Advanced Stirling Convertor Engineering Unit, second generation } \\ \text { Alumina } & \text { Aluminum Oxide } \\ \text { Au vs. Pt } & \text { Gold Versus Platinum } \\ \text { CAD } & \text { Computer-Aided Design } \\ \text { emf } & \text { Electromotive Force } \\ \text { GRC } & \text { Glenn Research Center } \\ \text { PVD } & \text { Physical Vapor Deposition } \\ \text { Pt-13\% Rh } & \text { Platinum-13\% Rhodium } \\ \text { Pt vs. Pd } & \text { Platinum Versus Palladium } \\ \text { RTD } & \text { Resistance-Temperature Detector }\end{array}$

\subsection{Introduction}

NASA Glenn Research Center (GRC) has been testing high-efficiency free-piston Stirling convertors for potential use in radioisotope power systems since 1999. Stirling convertors are being operated for many years to demonstrate a radioisotope power system capable of providing reliable power for 
long-duration missions of up to $14 \mathrm{yr}$. Accelerated life testing can be performed to provide life and reliability data but this type of testing is often performed on individual components and is not possible with a complete Stirling convertor because the parameter used to accelerate the life of one component may be detrimental to another component (Ref. 1). Reliable operation can be characterized by changes in performance or degradation but must be characterized with convertors under nominal operation typical of a mission, not under off-nominal conditions (Ref. 2).

GRC has had Stirling convertors on extended operation since 2003. The term extended operation describes continuous operation with shutdowns only

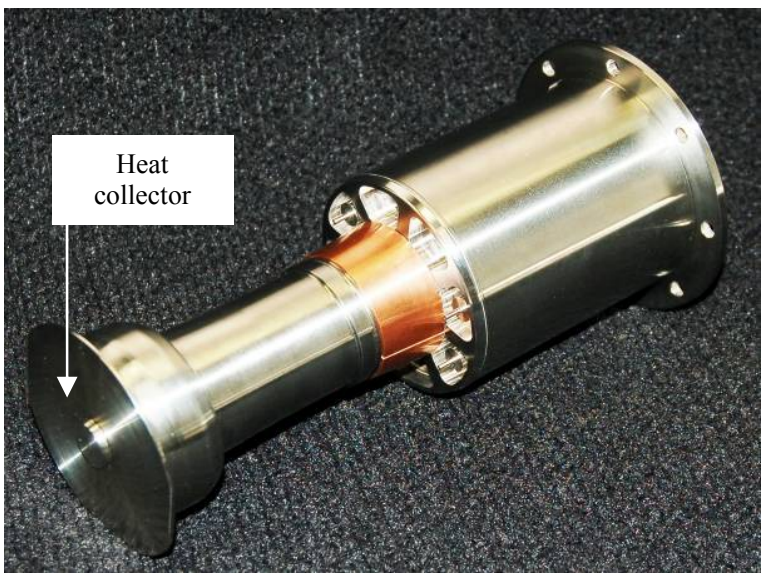

Figure 1.-Advanced Stirling Convertor Engineering Unit (ASC-E). Mass model shown. as required by facility issues. Techniques used to monitor the convertors for change in performance or degradation during extended operation include measurements of temperature, pressure, piston position, specie concentration levels in the working gas, and vibration and acoustic emissions. Parameters like thermal energy addition and rejection are calculated based on correlations developed prior to extended operation. Insulation is used in the Stirling test setup to minimize the loss of thermal energy from the electric heat source to the environment. Figure 1 shows a mass model of the Advanced Stirling Convertor Engineering Unit (ASC-E) being tested at GRC.

Net heat input to the Stirling convertor is used to calculate a convertor's thermal efficiency by dividing the electric power output by the net heat input. The net heat input is typically calculated using a correlation based on results from insulation characterization testing performed prior to extended operation (Ref. 3). The correlation is a function of gross electric power input to the heat source and Stirling operating temperatures. As the insulation ages during testing, the insulation thermophysical properties change. The net heat input correlation cannot account for changes in insulation performance which introduces errors in the correlation making it difficult to distinguish the difference between a change in convertor operating point and a change in convertor performance when calculating convertor thermal efficiency. To improve the accuracy of calculated net heat input and convertor thermal efficiency, a heat flux sensor was proposed to directly measure the heat transfer from the heat source to the Stirling convertor.

There are various designs of heat flux sensors, such as Gardon gauges, plug gauges, and thin film thermocouple arrays (Refs. 4 to 6). The thin film types have the advantage of high frequency response and minimal flow and thermal disturbance (Ref. 7). All heat flux sensors operate by measuring the temperature difference across a thermal resistance, based on Fourier's law of heat conduction seen in Equation (1).

$$
Q=-k \frac{\partial T}{\partial x}
$$

The heat flux $(Q)$ is in $\mathrm{W} / \mathrm{m}^{2}$, thermal conductivity $(k)$ is in $\mathrm{W} / \mathrm{m} /{ }^{\circ} \mathrm{C}$, and the temperature gradient at the sensor surface $(d T / d x)$ is in ${ }^{\circ} \mathrm{C} / \mathrm{m}$. In practice, Equation (1) is implemented by measuring the finite temperature difference, $\Delta T$, across a thermal resistance of the finite thickness, $\Delta x$, as shown in Equation (2).

$$
Q \approx-k \frac{\Delta T}{\Delta x}
$$


The temperature difference can be measured by thermocouples or an Resistance-Temperature Detector (RTD) arranged as a Wheatstone bridge (Ref. 8). In any case, it is desirable that the temperature sensors themselves be in as good thermal contact as possible with the substrate, and at the same time not interfere with the transfer of heat through the substrate. Thin film sensors are ideal for this application (Ref. 9).

\subsection{Thermal Analysis}

The heat source contains resistance cartridge heaters which are electrically powered using a variable direct current $(\mathrm{dc})$ power supply and PID controller. The cartridge heaters are mounted in the nickel heat block which is preloaded against the ASC-E heat collector. Figure 2 shows the components that make up the heat flux sensor assembly including the heat source, spacers present on each side of the heat flux sensor, and a simplified version of the Stirling heat collector. The red surfaces shown on the heat source represent the surfaces heated by the six cartridge heaters. The blue surface on the Stirling heat collector represents the control surface which is the hot end of the Stirling convertor. Thermal analysis was performed using a commercial finite element analysis code to estimate temperatures trends throughout the assembly based on constant heat input boundary condition on the red surfaces in the heat source and a constant temperature boundary condition on the blue surface in the heat collector. Because the heat flux measurement is inherently independent of heat loss through the insulation package that surrounds the heat flux sensor assembly, insulation heat loss was not considered but is expected to be around $30 \mathrm{~W}$. The analysis was performed for different values of gross heat input ranging from a possible $300 \mathrm{~W}$ to an unlikely $360 \mathrm{~W}$. Table I, located in the appendix, shows the minimum, maximum, and average temperatures for each side of the heat flux sensor. The net heat transfer through the heat flux sensor was calculated based on the (1) resulting integral average temperatures for each side of the heat flux sensor, (2) geometry of the conduction path, and (3) the alumina temperature dependent thermal conductivity. The resulting net heat transfer through the heat flux sensor ranged from 217 to $258 \mathrm{~W}$ as expected. The temperature gradients shown in Figure 3 are results from the extreme case of $360 \mathrm{~W}$ gross heat input. The exploded view of the assembly and both sides of the heat flux sensor are shown.

The thermal analysis results suggest the temperature difference across the thickness of the heat flux sensor substrate could range from 39 to $48{ }^{\circ} \mathrm{C}$. The maximum radial temperature difference across the face of the heat flux sensor could range from 30 to $39^{\circ} \mathrm{C}$. However, most of the change in temperature on a face resulted near the outer edge of the disk, as shown in Figure 3(b). The sensor has a slightly larger outer diameter than the nickel spacers that surround it to enable wire connections. That outer portion of the disk accounts for about $31^{\circ} \mathrm{C}$ difference in face temperature ( 84 percent) while the larger area, having a relatively uniform temperature across the face of the disk, accounts for about a $6{ }^{\circ} \mathrm{C}$ difference in face temperature (16 percent). The thin-film thermocouples are located in the mostly uniform temperature distribution, seen in Figure 3.

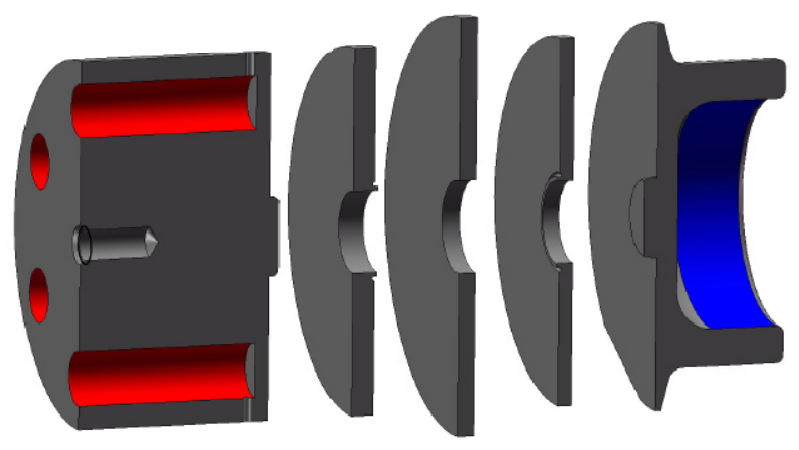

Figure 2.-Heat flux sensor assembly. Exploded view includes the heat source (left), spacer, heat flux sensor, spacer, and heat collector (right). 


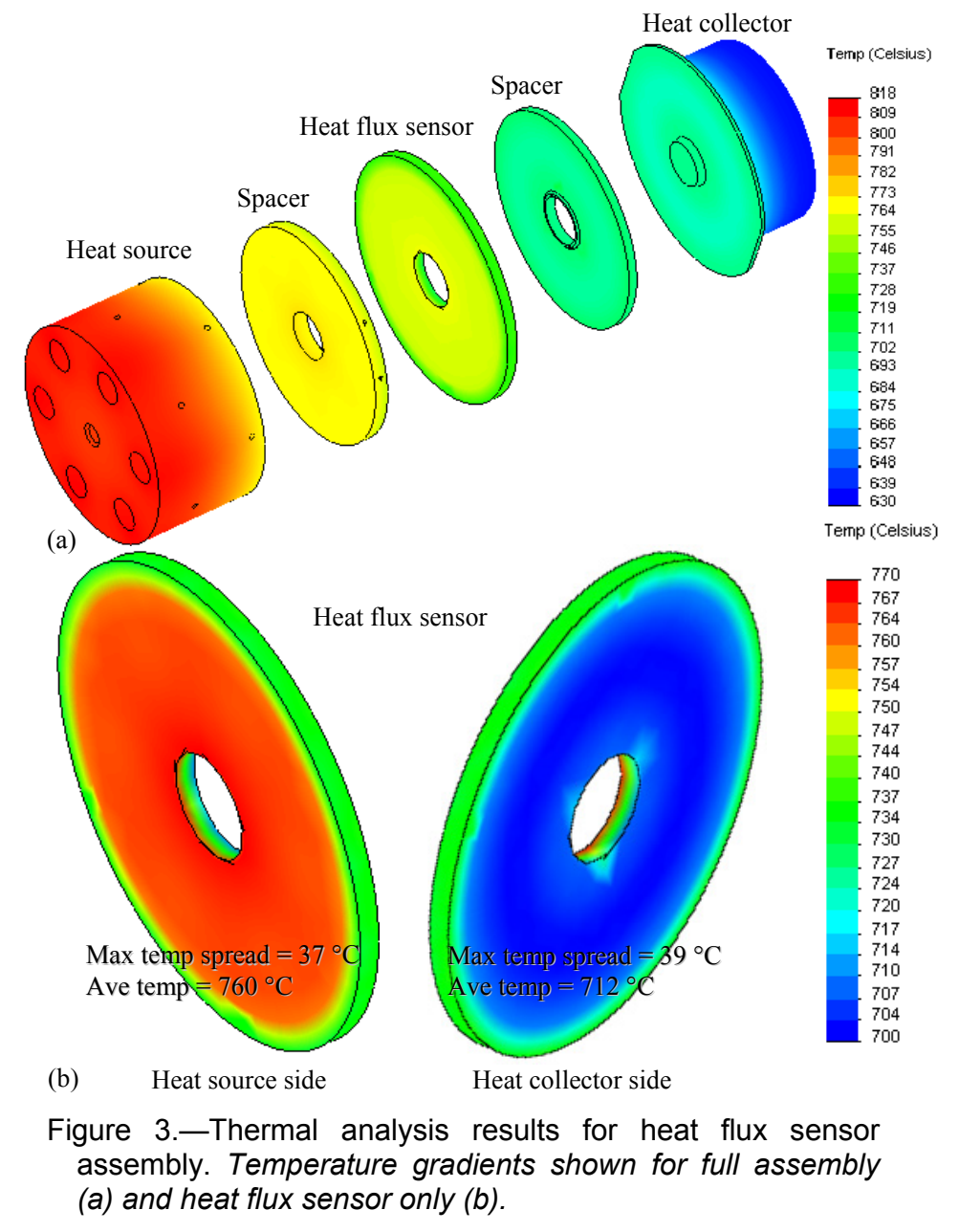

\subsection{Fabrication}

The heat flux sensor is made by depositing micro layers of noble metals onto a ceramic substrate. The substrates are fabricated and characterized by measuring the thermophysical properties. The thin-film thermocouples are then deposited onto the ceramic disk in a pattern designed for a particular application. Wires are attached to the thin-film thermocouple and the electromotive force (emf) voltage generated by the two dissimilar metals of the thermocouple is measured across the wires. In most cases, the noble metal wires coming from the thin-films need to transition to a less expensive, more durable wire used to interface the data acquisition system. This transition contains what is commonly referred to as the cold junction, the location where the noble metal wires are soldered to the extension wire. The cold junction represents an additional offset of junction emf voltage, which must be accounted for in the final calculation of junction temperature. After cold junction compensation is performed, the hot junction temperature can be determined. Cold junction compensation is discussed more in a later section.

\subsection{Ceramic Substrates}

The ceramic substrate thickness was chosen for the Stirling application based on desired temperature difference and the expected axial preload. The alumina substrates shown in Figure 4 were made via slipcasting, in which the powder was ball-milled in an aqueous solution, binders and dispersants were added, castings were bisque fired, and fully sintered. The disks were then machined to a thickness of 


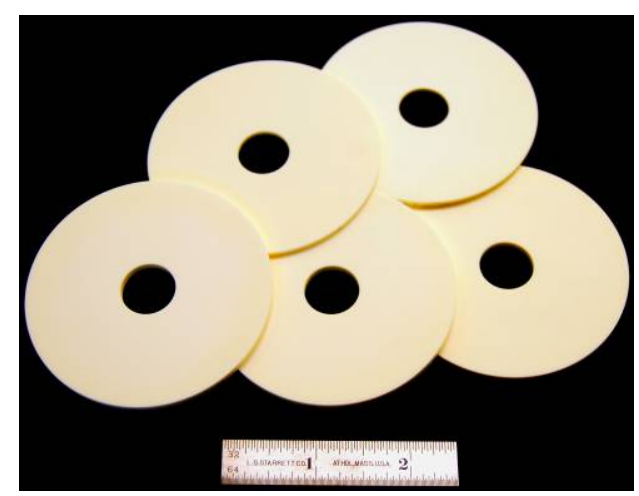

Figure 4.-Alumina ceramic substrates.

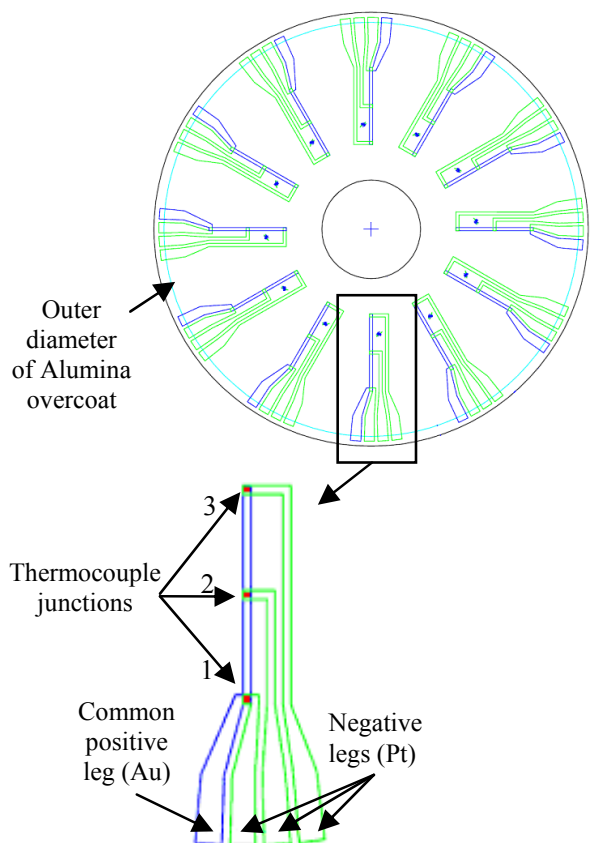

Figure 5.-Photolithography pattern. Measures radial variation in heat flux at two circumferential locations.

$0.120 \pm 0.00005$ in. with a near mirror surface finish. The thermophysical properties were then measured for the ceramic disks fabricated. Thermal conductivity tests were performed according to the specifications of ASTM E1461 test method. The Flash-Line 300 System (Anter Corporation) was used to perform thermal conductivity measurements with an expanded uncertainty of \pm 2.1 percent for 95 percent confidence limit. These measurements were made in flowing $\mathrm{N}_{2}$ at GRC. Five samples were randomly selected from alumina substrates fabricated by the GRC Ceramics Branch during 2009. For each laser measurement, three consecutive laser pulses were used to obtain an average thermal diffusivity. For each temperature, up to 13 measurements were repeated to obtain the statistical confidence level.

\subsection{Thin-Film Deposition}

The negative and positive legs of the photolithography pattern can be seen in Figure 5. Three thermocouple junctions are present in every array. Each side of the sensor has an arrangement of 12 thermocouple arrays although only two arrays are wired and the other 10 are spares. Each array has a mirrored array on the other side of the disk to enable measurement of the temperature difference, $\Delta T$ in Equation (2), across the thickness of the disk. The pattern shown in Figures 5 and 6 measures the heat flux at various radial and circumferential locations. The heat flux was expected to be highest directly under the cartridge heaters present in the heat source so a pattern of thermocouple junctions were located under the footprint of each heater, as shown in Figure 6(a). The same array can be found between each heater to measure heat flux variation in the circumferential direction. Each array has three junctions arranged from center to edge on the disk to enable measurement of heat flux variation in the radial direction. Junction 1, shown in Figure 5, was located toward the outer diameter of the disk, junction 2 was located under the heater, and junction 3 was located closer to the inner diameter of the disk. The sensors were designed to measure radially and circumferentially varying heat flux, although thermal analysis suggests this variation is small. Figure 6(b) shows the thermocouple arrays present on both sides of the disk to enable measurement of the temperature drop through the disk. 
The first heat flux sensor test pieces were fabricated using mullite ceramic substrates and thin-film Type-R thermocouples and wires. The mullite ceramic discs were fabricated at GRC. The mullite substrates were made via slipcasting, bisque fired, rough machined, fully sintered, and finish machined. The thin-film deposition was also performed at GRC using the Physical Vapor Deposition method. Films of ultra high purity (99.99 percent) were sputtered in vacuum. The deposition process went as planned until contamination issues, thought to be caused by a photo-resist reaction, prevented successful photolithography deposition. To remedy the problem, the deposition method was switched to using shadow masks and a new pattern was created which limited the heat flux measurements to a single radial location. The shadow mask deposition process was successful, but the bond strength of the Pt-13\% Rh (Type-R) films was inadequate on the mullite disks. The mullite substrates were then replaced by alumina substrates and photolithography was attempted once again.

The fabrication process was successful using Type- $\mathrm{R}$ thermocouples deposited onto alumina substrates. The next obstacle was getting the signals out of the sensor. To do this, small-diameter noble metal wires $(0.003$ in.) were parallel gap welded onto the thin noble metal films $\left(3.9 \times 10^{5}\right.$ in.). The platinum wires were welded to the thin-films without any issues while the $\mathrm{Pt}-13 \% \mathrm{Rh}$ wires were not successfully bonded using the parallel gap welding method. Laser welding was also attempted, but the variability in that process resulted in a low success rate. The decision was made to attempt a new combination of noble metals for the photolithography pattern to enable wire attachment.

Gold films were substituted for the Pt-13\% Rh films. The gold versus platinum ( $\mathrm{Au}$ vs. $\mathrm{Pt}$ ) thermocouples have very good stability, a slightly higher output and lead wire attachment was less problematic (Refs. 10 and 11). The $\mathrm{Au}$ versus Pt output signal is 1.5 times higher than that of Type-R thermocouples. The only drawback was that the

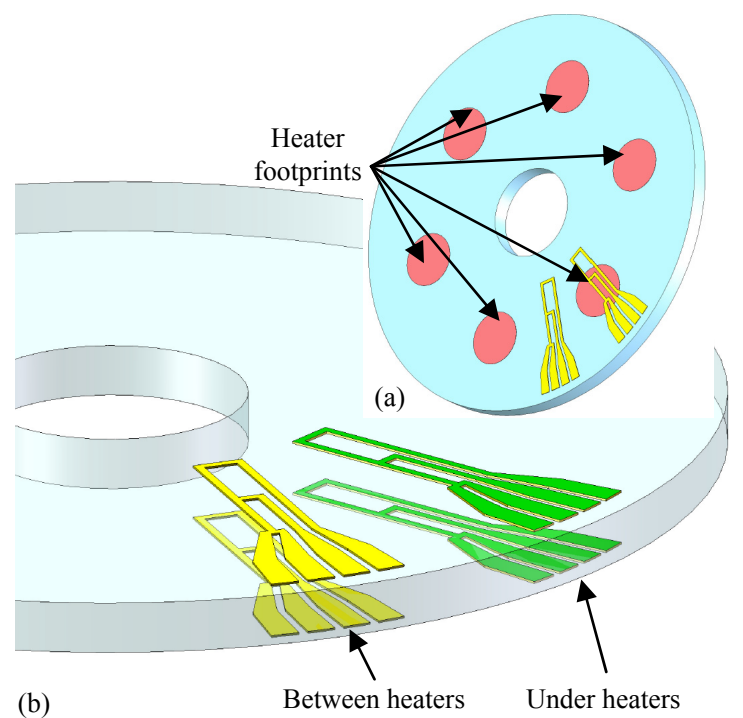

Figure 6.-Thermocouple arrangement. Thin-film thermocouple pattern used to measure disk surface temperatures under and between expected hot areas where heaters are located in the heat source (a), thermocouple array present on both sides of disk, disk shown transparent (b).

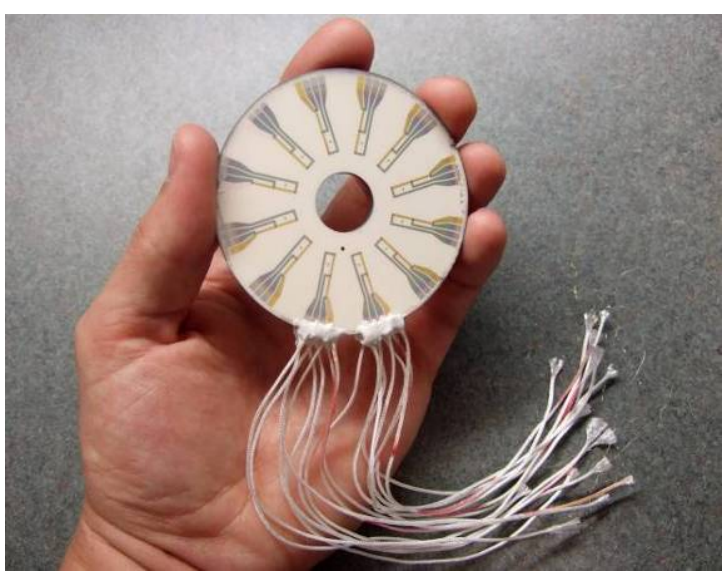

Figure 7.-Heat flux sensor. Au versus $P t$ thin-film thermocouples on Alumina ceramic substrate. melting point of gold $\left(1,064{ }^{\circ} \mathrm{C}\right)$ precluded using this design for a hot-end temperature of $850{ }^{\circ} \mathrm{C}$ because the anticipated heat source temperature could exceed $1,000^{\circ} \mathrm{C}$. Still suitable for a hot-end temperature of $650{ }^{\circ} \mathrm{C}$, the sensors were fabricated for use on ASC-E nos. 1 and 4 . The fabrication process was successful using $\mathrm{Au}$ versus Pt thermocouples deposited onto alumina substrates in January 2009. Figure 7 shows one heat flux sensor with small-diameter noble metal wires insulated using alumina fiber wire insulation which has an inner diameter of 0.012 in. and a maximum operating temperature around $1,200{ }^{\circ} \mathrm{C}$. A series of ceramic substrates and an instrumented Au versus Pt sensor were tested during component testing discussed in the next section. Component testing identified the unresolved issue of low bond strength between the gold films and alumina substrate. One sensor was damaged while being handled, so an additional sensor was fabricated. The replacement sensor was able to be fabricated in 3 weeks. 


\subsection{Component Testing}

The metallic and ceramic components being considered for use in the heat flux sensor assembly were tested to characterize the survivability and identify areas of improvement for design and/or fabrication techniques. The test subjected samples to conditions expected in the intended application including temperature transients, peak temperatures, and mechanical loading. The test identified: (1) available margin in mechanical load and thermal transients, (2) possible failure modes for the ceramic and metallic components, (3) required improvements for metallic spacer fabrication, and (4) a combination of materials for minimum temperature drop across the heat flux sensor assembly.

The test setup included parts necessary to apply the mechanical load and temperature difference to the test articles. Figure 8 shows a computer-aided design (CAD) image of the load assembly, heat source, test articles, and a simulated Stirling heat collector. The test articles included different combinations of metallic and ceramic parts required for the heat flux measurement in the Stirling

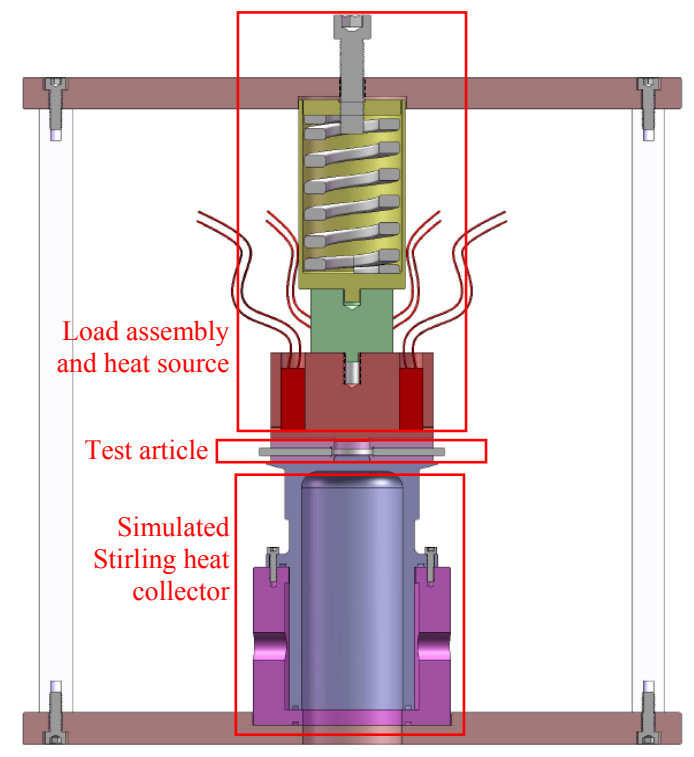

Figure 8.-Heat flux sensor component test setup. CAD image shown. application.

Six combinations of test article were tested including alumina and mullite ceramic substrates, nickel and alumina spacers, and nickel disks with and without nickel oxide layers and aluminum oxide layers. The nickel oxide layers were used to prevent diffusion bonding of the nickel parts at high temperature and the aluminum oxide layers were used to electrically insulate the face of the nickel disk planned to interface the sensor. Overall, the ceramic substrates held up exceptionally well under mechanical loads, thermal cycling, and peak temperatures similar to those expected in the application. Alumina substrates were tested using an axially applied mechanical load from 400 to $475 \mathrm{lb}$. The highest load tested provides about a 60 percent margin over the $300 \mathrm{lb}$ load expected in Stirling testing. These results suggest the substrates have an adequate compressive strength for the intended application. Some substrates selected for test contained hairline cracks. Those substrates did not change during the test, suggesting hairline cracks do not pose a significant risk to crack propagation in the substrate during normal use. While no substrates containing defects would be selected for fabrication, there was an interest in learning how defects affect performance of the ceramic disks.

The ceramic substrates were tested using a maximum temperature change rate of $0.5{ }^{\circ} \mathrm{C} / \mathrm{sec}$. The highest rate tested provides a 100 percent margin over the $0.25^{\circ} \mathrm{C} / \mathrm{sec}$ expected in Stirling testing. Values as high as $1.5^{\circ} \mathrm{C} / \mathrm{sec}$ were experienced during transients but only for a few seconds. These results suggest the ceramic discs have adequate resistance to thermally induced stresses which may occur while the Stirling convertor is being heated up or cooled down.

The nickel spacer discs appeared unaffected by mechanical loading. A layer of aluminum oxide was deposited onto the nickel spacers to electrically insulate the thermocouple array present on the sensor. These thin layers of aluminum oxide are expected to also provide protection against chemical reactions. The gold, platinum, and platinum/rhodium thin metallic films were present on the ceramic substrate on one of the samples before testing. These films were damaged in some areas on each side of the sensor. It appeared that the surface flatness on the nickel spacer was not adequately controlled, which resulted in damage to the thin-film thermocouples. 
Component testing identified the need to control the spacer geometry more closely in order to minimize contact resistance and prevent rough surfaces from damaging the thin films on the sensor. The nickel spacers were used to provide locating features for the sensor relative to the heat collector and heat source and to evenly distribute heat transfer from the heat source to the sensor.

\subsection{Sensor Integration}

Integrating the sensor into the Stirling convertor test setup involved converting the sensor thermocouple emf voltages into temperatures used to calculate heat transfer. The emf voltage signals feed out from the sensor through the small-diameter noble metal wires to a custom made wire feed through mounted in the insulation enclosure. The small-diameter noble metal wires were soldered to the copper feed through wires. These soldered junctions represent the cold junction of the circuit. In general, to perform cold junction compensation, a reference temperature measurement is required at the intermediate junction between the noble metal wire and the extension wire used to pass the signal along long lengths, often unsuitable for expensive and delicate noble metal wires. Type-T reference thermocouples were installed in the custom wire feed throughs and potted to the solder junctions using an electrically insulating, thermally conductive epoxy in order to accurately measure the cold junction reference temperature. The reference temperature was converted to a voltage using the Au versus Pt reference functions produced by National Institute of Standards and Technology (NIST) and added to the sensor output before being converted back to a temperature using the same reference functions. The Au versus $\mathrm{Pt}$ reference functions were developed by NIST during an investigation which quantified the stability and reproducibility of $\mathrm{Au}$ versus $\mathrm{Pt}$ wire thermocouples (Ref. 10). Small-diameter $\mathrm{Au}$ versus Pt wire thermocouples were subjected to thermal shock from $960{ }^{\circ} \mathrm{C}$ to room temperature 112 times during $1,000 \mathrm{hr}$ of operation. The resulting equivalent temperature changes of the thermocouple at the freezing point of silver did not exceed $\pm 16 \mathrm{~m}^{\circ} \mathrm{C}$. Further, the mean values of emf voltage obtained at full immersion for six Ag freezes were identical to within the equivalent of $1 \mathrm{~m}^{\circ} \mathrm{C}$. The NIST reference functions were programmed into the data acquisition system and used to convert the sensor output emf voltage to temperature.

The output available from $\mathrm{Au}$ versus Pt thermocouples ranges from 6 to $17,000 \mu \mathrm{V}$ while the thermocouple signal strength expected during steady state operation in the Stirling application ranges from 8,000 to $12,000 \mu \mathrm{V}$. Similarly, the total output resolution ranges from 6 to $25 \mu \mathrm{V} /{ }^{\circ} \mathrm{C}$ while the output resolution expected during steady state operation ranges from 18 to $24 \mu \mathrm{V} /{ }^{\circ} \mathrm{C}$.

A bench top test was performed at GRC to characterize the repeatability and stability of the Au versus $\mathrm{Pt}$ thin-film thermocouples fabricated at GRC and to test the proposed data acquisition process. The test setup, shown in Figure 9, includes (1) a thin-film Au versus Pt thermocouple deposited on an alumina substrate, used as the test article, (2) a Au versus Pt 0.003 in. diameter wire thermocouple located directly on top of the thin-film thermocouple via ceramic paste, used as the reference thermocouple, and (3) a Minco mica heater used to heat the test setup. The test setup was insulated and the noble metal thermocouple wires were soldered to the copper extension wire to create the cold junction. A Type-K thermocouple was used to measure the cold junction temperature. Testing characterized the thin-film thermocouple up to $495^{\circ} \mathrm{C}$ by comparing the thin-film thermocouple output to the output of the highly accurate wire reference thermocouple, also fabricated at GRC.

The transient test was used to characterize the repeatability of the thin-film thermocouple. The test setup measured emf voltages as a function of temperature. A computer commanded a dc power supply and heater to heat the test article from 50 to $450{ }^{\circ} \mathrm{C}$. The test article was then allowed to cool down to $50{ }^{\circ} \mathrm{C}$ before another thermal cycle was automatically performed. These test conditions were used to subject the test article to 15 thermal cycles. Throughout each thermal cycle, LabVIEW (National Instruments Corporation) was commanded to record the emf voltages at a scan frequency of $2 \mathrm{sec}$. The emf voltages from both thermocouples were then converted to temperature using the NIST reference functions and the cold junction temperature. Figure 10 shows the resulting emf voltage versus reference temperature from 


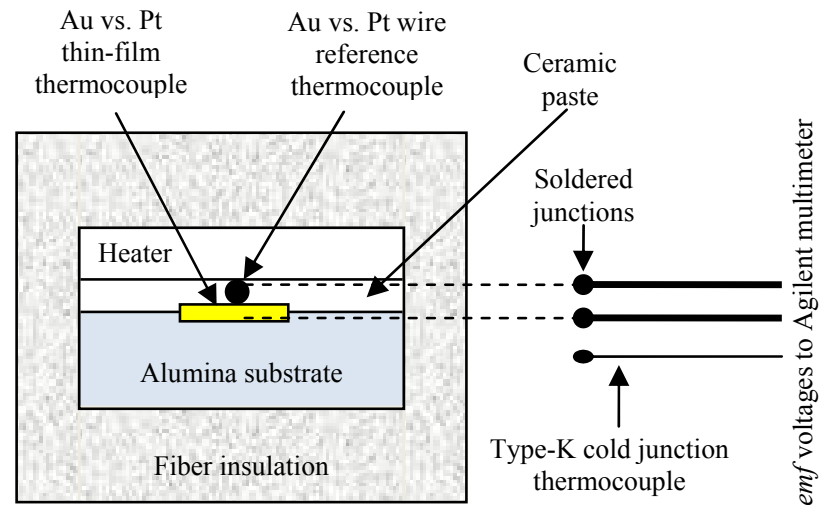

Au and Pt wire $\mathrm{Cu}$ extension wire

Figure 9.-Bench Top Test Setup. Includes a thin-film $A u$ versus $P t$ thermocouple, Au versus $P t$ wire thermocouple, and heater.

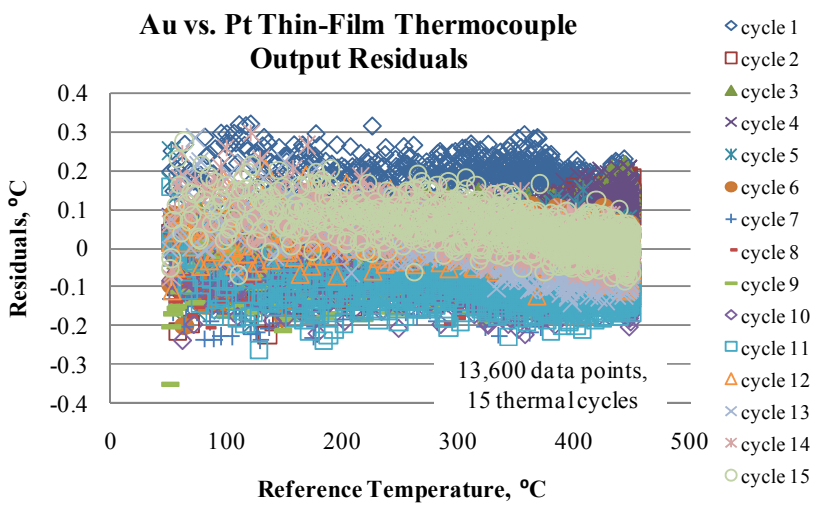

Figure 11.-Au versus Pt thin-film thermocouple data. Calculated residuals for heated periods only from all 15 thermal cycles.

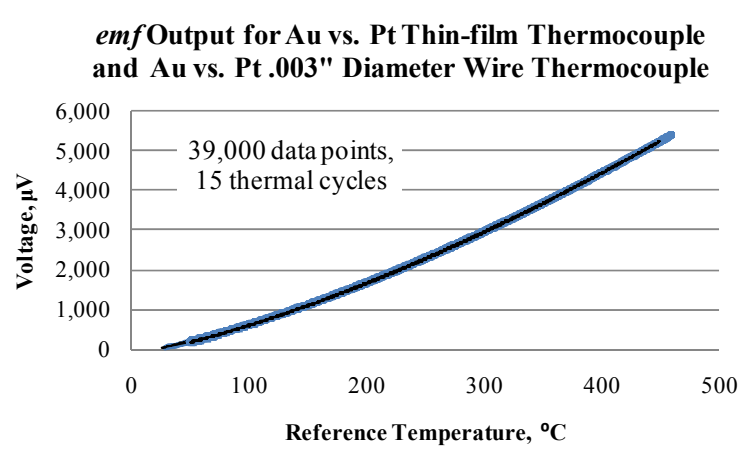

Figure 10.-Emf voltage versus temperature for $\mathrm{Au}$ versus $\mathrm{Pt}$ thin-film and wire thermocouples. Over 39,000 data points shown.

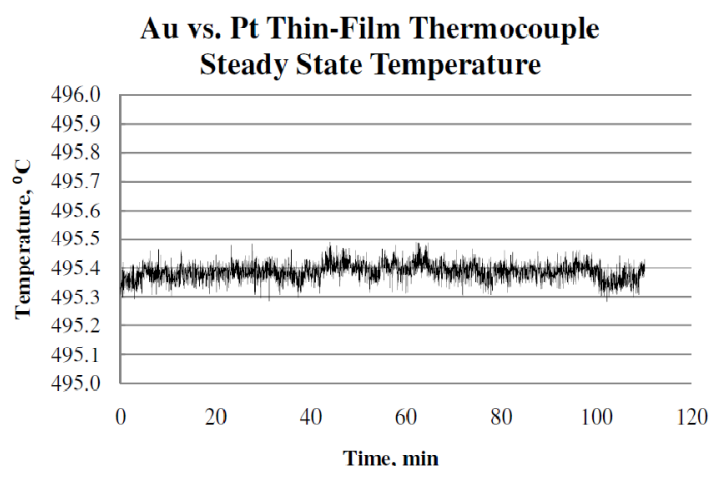

Figure 12.-Au versus $\mathrm{Pt}$ thin-film thermocouple data. Steady State Temperature.

15 thermal cycles. There was a maximum difference of $9{ }^{\circ} \mathrm{C}$ between the thin-film and wire thermocouples, likely due to the thermal resistance of the ceramic paste used to fix the wire thermocouple onto the thin-film thermocouple. Figure 11 shows the resulting residuals for only the heated periods of all 15 thermal cycles. The residuals were calculated by first calculating the temperature difference between the thin-film thermocouple temperature and the reference thermocouple temperature and then by subtracting that temperature difference from the 15-cycle average temperature difference. This was performed for each $2 \mathrm{sec}$ data record. The maximum temperature variation did not exceed $\pm 0.35{ }^{\circ} \mathrm{C}$.

A steady-state test was used to characterize the stability of the thin-film thermocouple. The test setup maintained a steady-state temperature of $495{ }^{\circ} \mathrm{C}$ (heater temperature limit). Throughout the test, LabVIEW was commanded to record the emf voltages at a scan frequency of $2 \mathrm{sec}$. The emf voltages from both thermocouples were then converted to temperature using the NIST reference functions and the cold junction temperature. Figure 12 shows the steady-state temperature data from the thin-film thermocouple. The maximum temperature variation, or random error, did not exceed $\pm 0.1{ }^{\circ} \mathrm{C}$. 


\subsection{High Temperature Heat Flux Sensor}

A heat flux sensor was being considered for use on ASC-E2's operating at a hot-end temperature of $850{ }^{\circ} \mathrm{C}$. The heat flux sensor turned out to be too invasive for the higher temperature setup because the temperature drop across the sensor drives the heat source temperature past its operating limit. For higher temperature operation, initial plans were to use platinum versus palladium ( $\mathrm{Pt}$ vs. $\mathrm{Pd}$ ) thermocouples, which are reported to be stable to $1,300{ }^{\circ} \mathrm{C}$ in an inert environment. However, both $\mathrm{Pt}$ and $\mathrm{Pd}$ have nonnegligible oxidation rates for in-air operating temperatures near $1,300{ }^{\circ} \mathrm{C}$ (Ref. 12). Long term use at very high temperatures will require the use of the semi-conductive oxides being developed by NASA as part of the Aviation Safety Program (Refs. 13 and 14). Because the sensors are fabricated from oxides, they are inherently stable in hot oxidizing atmospheres. Semi-conductive oxides also have very high outputs, which would make it possible to use thinner disks. The thinner disks enable a lower temperature drop across the sensor which makes the sensor less intrusive to the test setup.

\section{Conclusion}

A thin-film heat flux sensor was proposed to directly measure the heat transfer from the heat source to the Stirling convertor while in extended operation. Sensors were fabricated utilizing expertise in the Ceramics Branch, Sensors and Electronics Branch, and Thermal Energy Conversion Branch at GRC. Ceramic substrate fabrication techniques include slipcasting, bisque firing, fully sintering, finish machining, and measuring the ceramic thermophysical properties. Instrumentation fabrication techniques include using Physical Vapor Deposition to sputter 1- $\mu$ m-thick noble metal films of ultra high purity (99.99 percent) and parallel gap welding to attach small-diameter noble metal wires. Integration techniques include soldering small-diameter gold wires to a custom wire feed through and performing cold junction compensation for the nonstandard thermocouple. Component testing was performed to characterize margin in compressive load and thermal transients expected in Stirling convertor testing and to characterize the repeatability and stability of emf voltage output from the sensor. The development

effort identified materials, fabrication procedures, and data collection techniques required for measuring heat flux in a Stirling convertor. The sensors, to be used in ASC-E nos. 1 and 4 testing in 2009, contain gold versus platinum thermocouples deposited on alumina ceramic substrates. 


\section{Appendix.-Thermal Analysis Results for Heat Flux Sensor Assembly}

TABLE I.-THERMAL ANALYSIS RESULTS FOR HEAT FLUX SENSOR ASSEMBLY

\begin{tabular}{|c|c|c|c|c|c|c|c|c|}
\hline $\begin{array}{c}\text { Red } \\
\text { surface }\end{array}$ & $\begin{array}{c}\text { Blue } \\
\text { surface }\end{array}$ & \multicolumn{3}{|c|}{$\begin{array}{l}\text { HFS face, } \\
\text { Heater side }\end{array}$} & \multicolumn{3}{|c|}{$\begin{array}{l}\text { HFS face, } \\
\text { Stirling side }\end{array}$} & $\begin{array}{l}\text { Sensor heat } \\
\text { transfer }\end{array}$ \\
\hline $\begin{array}{l}\text { Gross heat } \\
\text { input, } \\
\text { W }\end{array}$ & $\begin{array}{c}\text { Constant } \\
\text { temperature, } \\
{ }^{\circ} \mathrm{C}\end{array}$ & $\begin{array}{c}\text { Max } \\
\text { temperature, } \\
{ }^{\circ} \mathrm{C}\end{array}$ & $\begin{array}{c}\text { Min } \\
\text { temperature, } \\
{ }^{\circ} \mathrm{C}\end{array}$ & $\begin{array}{c}\text { Ave } \\
\text { temperature, } \\
{ }^{\circ} \mathrm{C}\end{array}$ & $\begin{array}{c}\text { Max } \\
\text { temperature, } \\
{ }^{\circ} \mathrm{C}\end{array}$ & $\begin{array}{c}\text { Min } \\
\text { temperature, } \\
{ }^{\circ} \mathrm{C}\end{array}$ & $\begin{array}{c}\text { Ave } \\
\text { temperature, } \\
{ }^{\circ} \mathrm{C}\end{array}$ & $\begin{array}{c}\text { Net heat } \\
\text { input, } \\
\text { W }\end{array}$ \\
\hline $\begin{array}{l}300 \\
\text { a315 } \\
330 \\
345 \\
360\end{array}$ & $\begin{array}{l}630 \\
630 \\
630 \\
630 \\
630\end{array}$ & $\begin{array}{l}746 \\
751 \\
758 \\
764 \\
770\end{array}$ & $\begin{array}{l}715 \\
720 \\
724 \\
728 \\
733\end{array}$ & $\begin{array}{l}737 \\
743 \\
749 \\
754 \\
760\end{array}$ & $\begin{array}{l}721 \\
725 \\
730 \\
735 \\
739\end{array}$ & $\begin{array}{l}689 \\
692 \\
695 \\
698 \\
700\end{array}$ & $\begin{array}{l}698 \\
702 \\
705 \\
708 \\
712\end{array}$ & $\begin{array}{l}217 \\
227 \\
237 \\
248 \\
258\end{array}$ \\
\hline
\end{tabular}

${ }^{a}$ Anticipated operating point 


\section{References}

1. Schreiber, J.G. "Supporting Technology at GRC to Mitigate Risk as Stirling Power Conversion Transitions to Flight," Proceedings of the Sixth International Energy Conversion Engineering Conference (IECEC 2008), Cleveland, OH, August 2008.

2. Lewandowski, E.J., et al. "Extended Operation Testing of Stirling Convertors in Support of Stirling Radioisotope Power System Development," Proceedings of the Sixth International Energy Conversion Engineering Conference (IECEC 2008), American Institute for Aeronautics and Astronautics, Cleveland, OH, August 2008.

3. Oriti, S.M. and Cornell, P.A., "Processing and Preparation of Advanced Stirling Convertors for Extended Operation at NASA Glenn Research Center," Proceedings of the Sixth International Energy Conversion Engineering Conference (IECEC 2008) American Institute for Aeronautics and Astronautics, Cleveland, OH, August 2008.

4. Gardon, R., "An Instrument for the Direct Measurement of Intense Thermal Radiation, Review of Scientific Measurements," 24, 5, 1953, pp. 366-370.

5. Liebert, C.H., "Miniature High Temperature Plug-Type Heat Flux Gages," NASA TM-105403, April 1992.

6. Will, H., "Fabrication of Thin Film Heat Flux Sensors," Proceedings of the Third Health Monitoring Conference for Space Propulsion Systems," University of Cincinnati Press, pp. 348-355, Cincinnati, $\mathrm{OH}, 1991$.

7. Cho, C.S., Fralick, G.C., and Bhatt, H.D., "Steady State and Frequency Response of a Thin Film Heat Flux Gauge," Journal of Spacecraft and Rockets, vol. 34, no. 6, Nov-Dec 1997.

8. Fralick, G.C., Wrbanek, J.D., Blaha, C., "Thin Film Heat Flux Sensor of Improved Design," NASA/TM-2002-211566, September 2002.

9. Wrbanek, J.D., and Fralick, G.C., "Thin Film Physical Sensor Instrumentation Research and Development at NASA Glenn Research Center," NASA/TM-2006-214395, ISA\# TP06IIS023, September 2006.

10. Burns, G.W., Strouse, G.F., Liu, B.M., and Magnum, B.W., "Gold versus Platinum Thermocouple: Performance, Data and an ITS-90 based Reference Function," NIST, Gaithersburg, MD, in Temperature, Its Measurement and Control in Science and Industry, Ed. by J.F. Schooley, vol. 6, pp. 531-536, Amer. Institute of Physics, New York, 1992.

11. Blaha, C.A., "Liftoff Process of Difficult and Non-Etchable Material Using Photo-lithography," NASA Tech Briefs, March 2002.

12. Hill, K.D., "An Investigation of Palladium Oxidation in the Platinum-Palladium Thermocouple System," Metrologia, 2002, 39, 51-58.

13. Gregory, O.J., Busch, E., and Fralick, G.C., "Thermoelectric Properties of Ceramic Thin Film Thermocouples," ISA\# TP06IIS037, May 2006.

14. Wrbanek, J.D., Fralick, G.C., Farmer, S.C., Sayir, A., Blaha, C.A., and Gonzalez, J.M., "Development of Thin Film Ceramic Thermocouples for High Temperature Environments," NASA/TM-2004-213211, AIAA-2004-3549, August 2004. 


\begin{tabular}{|c|c|c|}
\hline \multicolumn{2}{|c|}{ REPORT DOCUMENTATION PAGE } & $\begin{array}{l}\text { Form Approved } \\
\text { OMB No. 0704-0188 }\end{array}$ \\
\hline \multicolumn{3}{|c|}{ 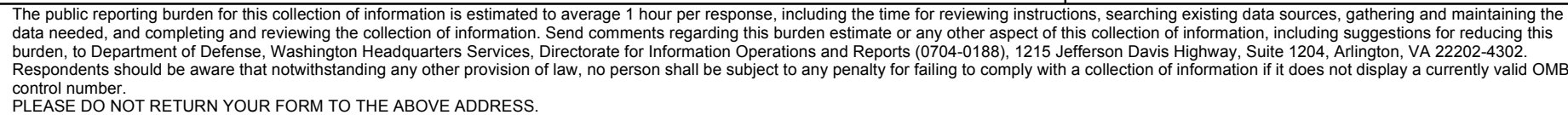 } \\
\hline $\begin{array}{l}\text { 1. REPORT DATE (DD-MM-YYYY) } \\
01-01-2010\end{array}$ & $\begin{array}{l}\text { 2. REPORT TYPE } \\
\text { Technical Memorandum }\end{array}$ & 3. DATES COVERED (From - To) \\
\hline \multirow{3}{*}{\multicolumn{2}{|c|}{$\begin{array}{l}\text { 4. TITLE AND SUBTITLE } \\
\text { Fabrication and Testing of a Thin-Film Heat Flux Sensor for a Stirl }\end{array}$}} & 5a. CONTRACT NUMBER \\
\hline & & 5b. GRANT NUMBER \\
\hline & & 5c. PROGRAM ELEMENT NUMBER \\
\hline \multirow{3}{*}{\multicolumn{2}{|c|}{$\begin{array}{l}\text { 6. AUTHOR(S) } \\
\text { Wilson, Scott, D.; Fralick, Gus, C.; Wrbanek, John, D.; Sayir, Ali }\end{array}$}} & $\begin{array}{l}\text { 5d. PROJECT NUMBER } \\
\text { NNCO8JF19T }\end{array}$ \\
\hline & & 5e. TASK NUMBER \\
\hline & & $\begin{array}{l}\text { 5f. WORK UNIT NUMBER } \\
\text { WBS } 138494.01 .04 .01\end{array}$ \\
\hline \multicolumn{2}{|c|}{$\begin{array}{l}\text { 7. PERFORMING ORGANIZATION NAME(S) AND ADDRESS(ES) } \\
\text { National Aeronautics and Space Administration } \\
\text { John H. Glenn Research Center at Lewis Field } \\
\text { Cleveland, Ohio 44135-3191 }\end{array}$} & $\begin{array}{l}\text { 8. PERFORMING ORGANIZATION } \\
\text { REPORT NUMBER } \\
\text { E-17101 }\end{array}$ \\
\hline \multirow{2}{*}{\multicolumn{2}{|c|}{$\begin{array}{l}\text { 9. SPONSORING/MONITORING AGENCY NAME(S) AND ADDRESS(ES) } \\
\text { National Aeronautics and Space Administration } \\
\text { Washington, DC 20546-0001 }\end{array}$}} & $\begin{array}{l}\text { 10. SPONSORING/MONITOR'S } \\
\text { ACRONYM(S) } \\
\text { NASA }\end{array}$ \\
\hline & & $\begin{array}{l}\text { 11. SPONSORING/MONITORING } \\
\text { REPORT NUMBER } \\
\text { NASA/TM-2010-216063; AIAA-2009- } \\
4581\end{array}$ \\
\hline \multicolumn{3}{|c|}{$\begin{array}{l}\text { 12. DISTRIBUTION/AVAILABILITY STATEMENT } \\
\text { Unclassified-Unlimited } \\
\text { Subject Category: } 20 \\
\text { Available electronically at http://gltrs.grc.nasa.gov } \\
\text { This publication is available from the NASA Center for AeroSpace Information, 443-757-5802 }\end{array}$} \\
\hline
\end{tabular}

\begin{tabular}{|l|}
\hline 13. SUPPLEMENTARY NOTES \\
\\
\hline
\end{tabular}

The NASA Glenn Research Center (GRC) has been testing high-efficiency free-piston Stirling convertors for potential use in radioisotope power systems since 1999. Stirling convertors are being operated for many years to demonstrate a radioisotope power system capable of providing reliable power for potential multiyear missions. Techniques used to monitor the convertors for change in performance include measurements of temperature, pressure, energy addition, and energy rejection. Micro-porous bulk insulation is used in the Stirling convertor test setup to minimize the loss of thermal energy from the electric heat source to the environment. The insulation is characterized before extended operation, enabling correlation of the net thermal energy addition to the convertor. Aging micro-porous bulk insulation changes insulation efficiency, introducing errors in the correlation for net thermal energy addition. A thin-film heat flux sensor was designed and fabricated to directly measure the net thermal energy addition to the Stirling convertor. The fabrication techniques include slipcasting and using Physical Vapor Deposition (PVD). One-micron-thick noble metal thermocouples measure temperature on the surface of an alumina ceramic disk and heat flux is calculated. Fabrication, integration, and test results of a thin-film heat flux sensor are presented.

15. SUBJECT TERMS

Heat flux sensor; Free-piston Stirling convertors; Radioisotope power systems

\begin{tabular}{|c|c|c|c|c|c|}
\hline \multicolumn{3}{|c|}{ 16. SECURITY CLASSIFICATION OF: } & \multirow{2}{*}{$\begin{array}{l}\text { 17. LIMITATION OF } \\
\text { ABSTRACT } \\
\text { UU }\end{array}$} & \multirow{2}{*}{$\begin{array}{l}\text { 18. NUMBER } \\
\text { OF } \\
\text { PAGES } \\
18\end{array}$} & \multirow{2}{*}{$\begin{array}{l}\text { 19a. NAME OF RESPONSIBLE PERSON } \\
\text { STI Help Desk (email:help@sti.nasa.gov) } \\
\text { 19b. TELEPHONE NUMBER (include area code) } \\
\text { 443-757-5802 }\end{array}$} \\
\hline $\begin{array}{l}\text { a. REPORT } \\
U\end{array}$ & $\begin{array}{l}\text { b. ABSTRACT } \\
U\end{array}$ & $\begin{array}{l}\text { c. THIS } \\
\text { PAGE } \\
\text { U }\end{array}$ & & & \\
\hline
\end{tabular}



